\title{
Optimizing hepatitis C therapy in HIV/hepatitis C virus (HCV) coinfected patients: Analysis of HCV viral kinetics on treatment
}

\author{
Paul Damien James MD MSc${ }^{1}$, David KH Wong MD²
}

\author{
PD James, DKH Wong. Optimizing hepatitis $\mathrm{C}$ therapy in HIV/ \\ $\mathrm{HCV}$ coinfected patients: Analysis of $\mathrm{HCV}$ viral kinetics on \\ treatment. Can J Infect Dis Med Microbiol 2012;23(1):31- \\ 35.
}

INTRODUCTION: Hepatitis C virus (HCV) infection is potentially curable, but the sustained virological response (SVR) has been shown to be lower in patients coinfected HIV. A single-centre experience treating individuals with HCV and HIV coinfection is reported. METHODS: Twenty-one patients who received standard doses of pegylated interferon with weight-based dosing of ribavirin (mean $14.3 \mathrm{mg} / \mathrm{kg}$ ) were retrospectively reviewed. Qualitative HCV polymerase chain reaction (PCR) was performed prospectively every four weeks if the patient remained HCV PCR positive. All patients with HCV genotype 1 were treated for 48 weeks. Patients with genotype 2 or 3 were treated for 24 weeks and 32 weeks to 36 weeks if their HCV RNA level was undetectable after four weeks (RVR4) or eight weeks (RVR8) of therapy, respectively. If RVR8 was not achieved, the treatment was continued for 48 weeks.

RESULTS: There were no dropouts or dose reductions within the first 12 weeks of treatment. SVR status was available for 20 patients and adequate serum for viral kinetics analyses was available for 17 patients. Eighty per cent of the patients achieved SVR (50\% genotype 1; 100\% genotypes 2 and 3). The week 8 viral load remained elevated for all genotype 1 nonresponders.

DISCUSSION: High effectiveness rates were seen, particularly in patients with HCV genotype 2 and 3 who were treated for shorter durations. HCV viral loads after eight weeks of therapy helped distinguish patients with HCV genotype 1 who would respond to therapy.

Key Words: Coinfection; Hepatitis C virus; Human immunodeficiency virus; Sustained virological response; Treatment; Viral load

\section{L'optimisation de la thérapie de l'hépatite $\mathrm{C}$ chez les patients co-infectés par le VIH et le VHC : une analyse de la cinétique virale du VHC sur le traitement}

INTRODUCTION : L'infection par le virus de l'hépatite C (VHC) se soigne, mais on a observé que la réponse virologique soutenue (RVS) est plus faible chez les patients co-infectés par le VIH. Les chercheurs rendent compte de l'expérience monocentrique du traitement de personnes co-infectées par le VHC et le VIH.

MÉTHODOLOGIE : Les chercheurs ont procédé à l'analyse rétrospective de 21 patients qui avaient reçu des doses standard d'interféron pégylé associées à une dose de ribavirine fondée sur le poids (moyenne de $14,3 \mathrm{mg} / \mathrm{kg}$ ). La réaction en chaîne de la polymérase (PCR) qualitative du VHC était exécutée de manière prospective toutes les quatre semaines si celle-ci révélait que le patient demeurait positif au VHC. Tous les patients ayant un VHC de génotype 1 ont été traités pendant 48 semaines. Les patients ayant le génotype 2 ou 3 ont été traités pendant 24 semaines et 32 à 36 semaines si leur taux de VHC dans l'ARN n'était plus décelable au bout de quatre semaines (RVR4) ou de huit semaines (RVR8) de traitement, respectivement. Si on ne parvenait pas à une RVR8, le traitement était maintenu pendant 48 semaines.

RÉSULTATS : Il n'y a pas eu d'abandon ou de réduction des doses dans les 12 premières semaines du traitement. Les chercheurs connaissaient la RVS de 20 patients et les analyses sériques pertinentes de la cinétique virale de 17 patients. Quatre-vingts pour cent des patients ont obtenu une RVS (50\% des cas de génotype 1; $100 \%$ des cas de génotypes 2 et 3). La huitième semaine, la charge virale demeurait élevée pour tous les nonrépondants de génotype 1.

EXPOSÉ : Les chercheurs ont observé un taux d'efficacité élevé, particulièrement chez les patients ayant un VHC de génotype 2 ou 3 qui avaient été traités moins longtemps. La charge virale du VHC au bout de huit semaines de traitement contribuait à faire ressortir les patients ayant un $\mathrm{VHC}$ de génotype 1 qui répondaient au traitement.
$\mathrm{H}$ $\mathrm{V}$ and hepatitis $\mathrm{C}$ virus (HCV) are both bloodborne pathogens with shared routes of transmission; namely injection drug use the greatest risk factor with a 10-fold increased risk of HCV and HIV coinfection - and other important, but less dominant risk factors including men having sex with men, multiple sexual partners, unprotected sexual contact, exposure to blood products and spending time in jail. Approximately $25 \%$ to $50 \%$ of all HIV-infected patients have HCV coinfection (1-3).

With the emergence of effective HIV antiretroviral therapies, liver disease has become the leading cause of morbidity and mortality among HIV-infected persons (4). Prompt treatment of HCV should be considered in all patients with HIV coinfection. HIV - and HCVcoinfected persons progress to cirrhosis faster and are at an increased risk of death from end-stage liver disease compared with those infected with $\mathrm{HCV}$ alone $(5,6)$. Furthermore, HIV/HCV coinfection may be associated with resistance to highly active antiretroviral therapy (ART) and increased risk of progression to AIDS $(4,7)$.

Large, multicentre, double-blinded, randomized controlled trials have shown that treatment with pegylated interferon (PEG-IFN) and ribavirin have resulted in sustained virological response (SVR), defined as undetectable HCV RNA levels six months after the end of treatment, with SVR rates of $27 \%$ to $40 \%$ in HIV/HCV coinfected patients (8-10). These rates are considerably lower compared with the SVR rates in similar trials based on non-HIV-infected individuals with HCV (up to 63\%) (11).

Multiple reasons for the reduced response to treatment in the HIV/ $\mathrm{HCV}$ coinfected population have been proposed. First, the impaired immune response in many persons with HIV may reduce treatment efficacy. Second, lower rates of HCV therapy adherence were observed in previous trials. Some authors suggest that treatment tolerance is

${ }^{1}$ Department of Internal Medicine; ${ }^{2}$ Division of Gastroenterology and Hepatology, Department of Internal Medicine, Faculty of Medicine,

University of Toronto, Toronto, Ontario

Correspondence: Dr David KH Wong, University Health Network - Toronto Western Hospital, 6B Fell Room 176, 399 Bathurst Street,

Toronto, Ontario M5T 2S8. Telephone 416-603-6234, fax 416-603-5473, e-mail david.wong.uhn@gmail.com 
especially difficult because the adverse effects of ribavirin may be amplified ART (9). Third, and perhaps most importantly, early trials of HCV treatment in HIV-positive persons used fixed lower dosages of ribavirin compared with the weight-based ribavirin dosing commonly provided to HCV monoinfected patients.

Therapeutic trials of HCV monoinfected patients have demonstrated that weight-based dosing of ribavirin $(12 \mathrm{mg} / \mathrm{kg} / \mathrm{day}$ to $15 \mathrm{mg} / \mathrm{kg} / \mathrm{day})$ optimized SVR rates, especially in patients with the harder to treat HCV genotype 1 infections (11). Fixed lower-dose ribavirin regimens were adopted for the treatment of HCV in HIV coinfected patients due to safety concerns regarding the potential interaction between ribavarin and certain nucleoside analogues, such as mitochondrial toxicity (didanosine and stavudine) (9) and anemia (zidovudine) (12). A study analyzing pooled data from multiple trials, however, has found that higher doses of ribavirin can result in similar early virological response (EVR) rates for both HIV/HCV coinfected and HCV monoinfected patients (13). To date, the effectiveness of HCV therapy using weight-based ribavirin dosing on SVR has not been demonstrated in a HIV/HCV coinfected practice cohort.

Established indicators of treatment success in HIV/HCV coinfected patients are genotype (genotypes 2 and 3 have a more favourable response compared with genotypes 1 and 4), baseline pretreatment HCV viral load and EVR, defined as a $2 \log _{10}$ decline in HCV RNA or an undetectable viral load at 12 weeks of therapy (4,14-16). Although various authors have suggested that HCV viral genotype and viral load kinetics at four, eight and 12 weeks should be used to guide therapy duration, no study has described the impact of such a treatment regimen in the HIV/HCV coinfected patient population.

The purpose of the present study was to describe the experience of a single centre treating HIV/HCV coinfected patients. The Toronto General Hospital Immunodeficiency Clinic (Toronto, Ontario) has a single hepatologist on staff with a specific interest in liver diseases in those with HIV infection. HCV/HIV coinfected individuals were referred primarily from family physicians and infectious disease specialists from the region, a catchment area with a population of approximately four million. The clinic provides ready access to three clinical nurses, infectious disease specialists with expertise in HIV care, onsite phlebotomy and a specialized clinic pharmacy. Our study protocol was unique relative to previous cohort studies in this field because: weightbased ribavirin dosing has been implemented for all HCV genotypes since May 2002; HCV genotype and viral kinetics at four, eight and 12 weeks of treatment were routinely examined to determine duration of HCV therapy since March 2005; and treatment side effects, such as anemia or depression, were directly managed (eg, by providing erythropoietin or antidepressants) with a philosophy that dose reductions and dose interruptions are strategies of last resort.

\section{METHODS}

A retrospective cohort study of all HIV/HCV coinfected patients who initiated HCV treatment at the Toronto General Hospital Immunodeficiency Unit from May 2002 to March 2007 was conducted. The study was approved by the Review Ethics Board at the University Health Network and consent was obtained from the patients who were followed by the clinic at the time of data collection. All included patients were referred from either the HIV clinic or primary care providers in the community. $\mathrm{HCV}$ treatment was considered for all patients with HCV/HIV coinfection, but may not have been undertaken if the liver disease was not severe (estimated liver fibrosis F0 or F1), if liver disease was too severe (cirrhosis with decompensation), in the setting of active alcohol or drug abuse that may affect adherence to therapy, or if other comorbid conditions were deemed more severe and needed attention first.

A total of 67 patients with HIV/HCV coinfection were being followed by the Toronto General Hospital Immunodeficiency Unit between March 2005 and March 2007. The results of 21 consecutive individuals who began HCV therapy with PEG-IFN $\alpha 2$ a $180 \mu \mathrm{g} /$ week or PEG-IFN $\alpha 2 \mathrm{~b} 1.5 \mu \mathrm{g} / \mathrm{kg} /$ week and a weight-based dosing of ribavirin (aiming for $13 \mathrm{mg} / \mathrm{kg}$ ) during this time period are reported. HCV viral loads were determined at four, eight and 12 weeks after starting treatment and were used along with HCV genotype to guide duration of therapy as follows. All patients with genotype 1 were treated for 48 weeks if they had at least a $2 \log _{10}$ drop in viral load after 12 weeks of therapy (EVR). For patients with genotype 2 or 3, the appropriate duration of therapy was unclear because the standard practice at the time was 48 weeks of therapy for HCV/HIV coinfection, whereas it was 24 weeks for $\mathrm{HCV}$ monoinfection. Again, the clinic adopted an approach based on the on-treatment viral kinetics response. If the HCV RNA level was undetectable by polymerase chain reaction (PCR) (ie, $<50 \mathrm{IU} / \mathrm{mL}$ ) after four weeks of therapy (RVR4), treatment duration was 24 weeks. Patients who did not achieve RVR4 but had undetectable HCV RNA after eight weeks of therapy (RVR8) were treated for 32 weeks to 36 weeks. If RVR8 was not achieved and there was a $2 \log _{10}$ or more drop in viral load after 12 weeks (EVR), the treatment was continued for the full 48 weeks. Based on the patients' responses to questions regarding adherence, all of the patients started on HCV therapy followed their medication regimen as prescribed by the hepatologist. Treatment was abandoned due to futility if EVR was not achieved or if HCV PCR remained positive after 24 weeks of treatment. Successful treatment was defined as an SVR, that is, HCV PCR negative six months after cessation of therapy. The primary outcome of the present study was the SVR rate in this single-centre cohort. The HCV viral kinetics for each patient with available sera, and stratified by SVR (yes or no) for patients with HCV genotype 1 were charted.

Data obtained from electronic medical files included individual characteristics such as age, sex, weight, body mass index, CD4 counts, antiretroviral regimen, liver biopsy reports and liver function indicators. HCV viral load at baseline as well as at four, eight and 12 weeks on HCV therapy were quantified from stored sera.

The length of follow-up for 20 patients was sufficient to determine their SVR status (Figure 1). Of these 20 patients, 17 had sufficient sera collected to be included for determination of HCV viral kinetics at zero, four, eight and 12 weeks. These 17 patients are presented with the entire treatment cohort with sufficient follow-up for comparison.

Before analyzing the data, it was hypothesized that treatment with weight-based doses of ribavirin would result in higher rates of SVR in HIV/HCV coinfected patients treated at the author's centre compared with SVR rates described in previous studies; and in patients with HCV genotype 2 and 3, HCV RNA levels after four, eight and 12 weeks of treatment could effectively guide the duration of therapy.

\section{RESULTS}

Among the $21 \mathrm{HIV} / \mathrm{HCV}$ coinfected patients eligible for analysis, the mean age was 46 years, $90 \%$ were men and $42 \%$ had a history of injection drug use (Table 1). Liver biopsy results were available on 17 patients, eight of whom had grade 3 or 4 fibrosis. Of the four patients without liver biopsy data available, one had biochemical evidence of cirrhosis (an aspartate aminotransferase to platelet index $>2$ ). The median baseline CD4 cell count was 556 cells $/ \mathrm{mm}^{3}$ and mean HIV RNA level was 11,903 copies $/ \mathrm{mL}$. Fifty-two per cent of the patients had HCV genotype 1 and the rest were infected with genotype 2 or 3 . Most of the patients were taking ART at the time of HCV treatment onset. All of the patients on ART were taking a nucleoside reverse transcriptase inhibitor. Approximately one-half of the patients on ART were taking non-nucleoside reverse transcriptase inhibitors and approximately one-half were taking a protease inhibitor. The average ribavirin dose for the treatment of HCV was $14.3 \mathrm{mg} / \mathrm{kg}$.

There were no dropouts during the first 12 weeks of treatment. Two patients with genotype 1 were taken off HCV therapy after 12 weeks becasue they did not achieve an EVR. SVR was achieved in $80 \%$ of patients; $50 \%$ with genotype 1 and $100 \%$ with genotype 2 and 3 infections.

Figure 2 presents the HCV viral kinetics for the 17 patients with determined SVR status and sufficient sera available to measure HCV 


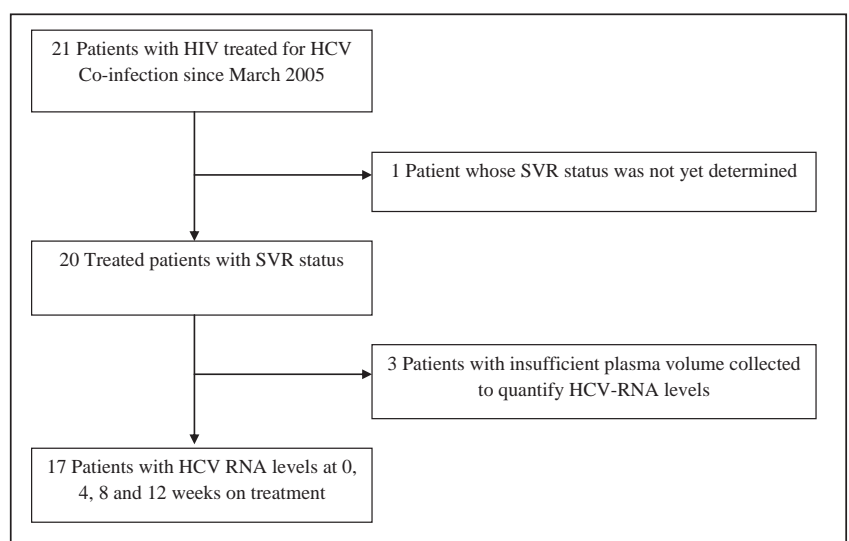

Figure 1) Study cohort. HCV Hepatits C virus; SVR Sustained virological response

RNA levels. For patients with HCV genotype 1, there is a clear indication that those patients who developed undetectable HCV RNA levels eight weeks after starting treatment went on to achieve SVR. All patients with genotype 2 and 3 demonstrated a significant response to treatment eight weeks after starting therapy, and all of them achieved SVR.

Regarding adverse events, none of the 21 patients in the present study developed hemoglobin levels of $<80 \mathrm{~g} / \mathrm{L}$ during the treatment period. One patient was transfused one unit of blood based on symptoms consistent with anemia. A nadir neutrophil count $<7.5 \times 10^{9} / \mathrm{L}$ was observed in 13 patients. None of these patients developed a significant new infection while on HCV therapy. The platelet count of two patients dropped below $0.50 \times 10^{9} / \mathrm{L}$ and neither patient reported significant bleeding. The blood counts of all of the patients who completed or stopped HCV therapy returned to their pretreatment levels. Three patients noted significant headaches and three patients were started on treatment for depression while on HCV therapy.

\section{DISCUSSION}

The response to HCV therapy has been repeatedly shown to be impaired for patients coinfected with HIV. In the experience of this single centre, the HCV treatment response in coinfected patients is not very different from those with HCV monoinfection when weightbased ribavirin is used; $80 \%$ of patients achieved SVR. This includes $100 \%$ of patients with $\mathrm{HCV}$ genotype 2 and 3, who were treated for a shorter duration based on their response at four and eight weeks. This level of response has not been previously demonstrated in patients with HIV/HCV coinfection.

We propose two main reasons for this elevated response to HCV treatment. First, the allied health staff in this clinic follow the HIV patient population closely to manage side effects and ensure treatment adherence. This includes regular patient visits to the clinic to discuss treatment progress with the nursing staff and identify barriers to adherence. Although many patients in this cohort experienced adverse effects such as anemia and depression, consistent with this treatment regimen, these side effects were routinely addressed and aggressively managed within the clinic.

Second, this clinic has been treating HCV with PEG-IFN and a weight-based ribavirin therapy since May 2002. These approaches are consistent with published guidelines from centres in the United States $(17,18)$ and Canada $(19)$; however, the potential impact of this protocol on treatment efficacy has not previously been evaluated.

To date, HCV trials of patients with HIV coinfection used levels of ribavirin that resulted in suboptimal treatment response rates. The present observational study demonstrates that with weight-based ribavirin therapy, the expected levels of HCV treatment success should be greater than previously published for this patient population.
TABLE 1

Patient characteristics at the start of treatment for HIVI hepatitis $\mathrm{C}$ virus (HCV) coinfection and the response to HCV therapy

\begin{tabular}{|c|c|c|}
\hline Characteristic & $\begin{array}{c}\text { All treated } \\
\text { patients } \\
(\mathrm{n}=21)\end{array}$ & $\begin{array}{l}\text { Patients } \\
\text { included in } \\
\text { the cohort } \\
(n=17)\end{array}$ \\
\hline Mean age, years & 46.6 & 46.5 \\
\hline Male sex & $19(90.4)$ & $15(88.2)$ \\
\hline Mean weight, $\mathrm{kg}$ & 78.1 & 76.5 \\
\hline Mean body mass index, $\mathrm{kg} / \mathrm{m}^{2}$ & 24.4 & 24.0 \\
\hline Evidence of cirrhosis* & $9(42.9)$ & $9(52.9)$ \\
\hline History of alcohol abuse ${ }^{\dagger}$ & $6(28.6)$ & $4(23.5)$ \\
\hline Drinking alcohol during treatment period & $12(57.1)$ & $11(64.7)$ \\
\hline \multicolumn{3}{|l|}{ Risk factors for HIV and HCV coinfection } \\
\hline Injection drug use & $9(42.9)$ & $7(41.2)$ \\
\hline Men having sex with men & $15(71.4)$ & $12(70.6)$ \\
\hline Unprotected sexual contact & $5(23.8)$ & $3(17.6)$ \\
\hline Exposure to blood products & $9(42.9)$ & $7(41.2)$ \\
\hline Spent time in prison & $5(23.8)$ & $3(17.6)$ \\
\hline Median CD4 cell count, number $/ \mathrm{mm}^{3}$ & 556 & 555 \\
\hline Mean HIV RNA level, copies/mL & 11,903 & 10,122 \\
\hline Baseline HIV RNA level, <50 copies/mL & $13(61.9)$ & $12(70.6)$ \\
\hline \multicolumn{3}{|l|}{ Antiretroviral therapy } \\
\hline Any & $15(71.4)$ & $13(76.5)$ \\
\hline Nucleoside reverse transcriptase inhibitor & $15(71.4)$ & $13(76.5)$ \\
\hline Non-nucleoside reverse transcriptase inhibitor & $7(33.3)$ & $6(35.3)$ \\
\hline Protease inhibitor & $7(33.3)$ & $6(35.3)$ \\
\hline \multicolumn{3}{|l|}{ Hepatitis C } \\
\hline HCV genotype 1 & $11(52.3)$ & $8(47.1)$ \\
\hline Mean baseline HCV RNA, IU/mL & $1,435,280$ & $1,470,477$ \\
\hline Baseline HCV RNA, $<800,000 \mathrm{IU} / \mathrm{mL}$ & $3(14.3)$ & $3(17.7)$ \\
\hline Average ribavirin dose, $\mathrm{mg} / \mathrm{kg}$ & 14.3 & 14.5 \\
\hline \multicolumn{3}{|l|}{$\mathrm{HCV}$ treatment response } \\
\hline RVR4 & $2(9.5)$ & $2(11.8)$ \\
\hline RVR8 & $14(66.7)$ & $11(64.7)$ \\
\hline EVR & $17(81.0)$ & $13(76.5)$ \\
\hline $\operatorname{SVR}^{\ddagger}$ & $17(80.0)$ & $13(76.5)$ \\
\hline
\end{tabular}

Data are presented as $n(\%)$, unless otherwise indicated. ${ }^{*}$ Cirrhosis was determined as follows: 8 of the 17 patients with liver biopsies available had grade 3 or grade 4 fibrosis; 1 of the 4 patients without liver biopsies available had an aspartate aminotransferase to platelet ratio index $>2$; ${ }^{\dagger}$ Alcohol abuse was defined as the consumption of more than 9 standard drinks of alcohol/week for women and 14 standard drinks of alcohol/week for men; ${ }^{\ddagger}$ Based on treated patients with a sustained virological response (SVR) status available $(n=20)$. EVR Early virological response after 12 weeks; IU International units; RVR4 Rapid virological response after 4 weeks; RVR8 Rapid virological response after 8 weeks

$\mathrm{HCV}$ viral kinetics have been used to estimate response to therapy and guide treatment duration in patients with HCV monoinfection (20); however, to date there has been a lack of evidence demonstrating that this avenue can also be applied to HIV coinfected patients. In a reanalysis of data from the Peginterferon Ribavirina España Coinfección (PRESCO) trial, Martin-Carbonero et al (16) showed that undetectable levels of HCV genotype 3 RNA after four weeks of treatment had a positive predictive value of $90 \%$ for SVR. In the present study, we demonstrated that HCV RNA levels eight weeks after starting therapy were associated with the achievement of SVR in HIV-positive patients with HCV genotype 1 coinfection treated for 48 weeks. We also observed that treating patients with HCV genotype 2 or 3 for a shorter period based on their HCV RNA level at four and eight weeks resulted 


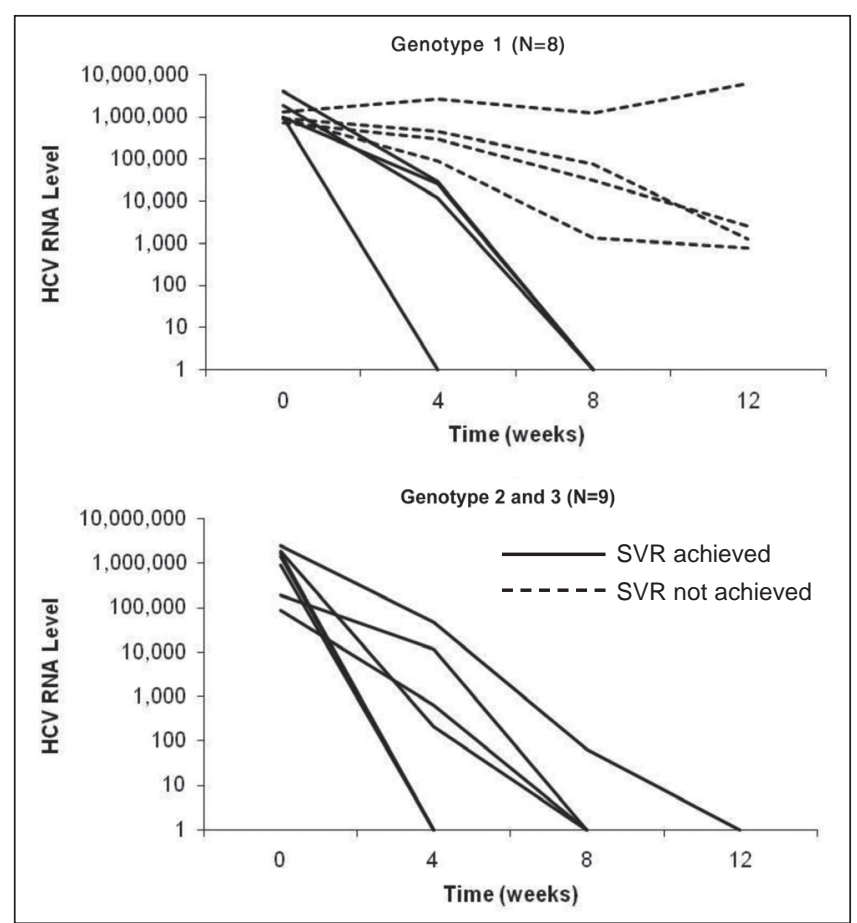

Figure 2) Hepatitis $\mathrm{C}$ virus (HCV) viral kinetics from 0 to 12 weeks for HIV-coinfected patients starting treatment for HCV. SVR Sustained virological response

in $100 \%$ SVR. All of these patients had a $2 \log$ decrease in HCV RNA levels by eight weeks on treatment. Offering reduced treatment duration has the clear benefit of limiting patient exposure to the harmful side effects of HCV therapy.

Various study limitations are worth mentioning. First, the present observational study was based on a small number of patients. As a result, we were unable to detect smaller differences between groups and could not adjust for potential confounders of HCV treatment response. Therefore, although we report high response rates as well as clear differences in HCV viral kinetics, these trends should be confirmed in larger prospective investigations.

Second, over a two-year period, this centre started treatment on $21 \mathrm{HIV} / \mathrm{HVC}$ coinfected patients. Recent reports have highlighted low referral rates for HCV treatment and various reasons for treatment

\section{REFERENCES}

1. Bollepalli S, Mathieson K, Jasiurkowski B, et al. A comparison of risk factors for HCV-mono-infection, HIV-mono-infection, and $\mathrm{HCV} / \mathrm{HIV}$-co-infection in a community setting. Dig Dis Sci 2008;53:517-21.

2. Bollepalli S, Mathieson K, Bay C, et al. Prevalence of risk factors for hepatitis $\mathrm{C}$ virus in HIV-infected and HIV/hepatitis $\mathrm{C}$ viruscoinfected patients. Sex Transm Dis 2007;34:367-70.

3. Buxton JA, Yu A, Kim PH, et al. HCV co-infection in HIV positive population in British Columbia, Canada. BMC Public Health 2010;10:225.

4. McGovern BH. Hepatitis $\mathrm{C}$ in the HIV-infected patient. J Acquir Immune Defic Syndr 2007;45(Suppl 2):S47-56; discussion S66-7.

5. Weber R, Sabin CA, Friis-Moller N, et al. Liver-related deaths in persons infected with the human immunodeficiency virus: The D:A:D study. Arch Intern Med. 2006 Aug 14-28;166(15):1632-41.

6. Graham CS, Baden LR, Yu E, et al. Influence of human immunodeficiency virus infection on the course of hepatitis $\mathrm{C}$ virus infection: A meta-analysis. Clin Infect Dis 2001;33(4):562-9.

7. De Luca A, Bugarini R, Lepri AC, et al. Coinfection with hepatitis viruses and outcome of initial antiretroviral regimens in previously naive HIV-infected subjects. Arch Intern Med 2002;162:2125-32. ineligibility such as psychiatric conditions and ongoing drug use $(21,22)$. For example, in an observational study of $845 \mathrm{HIV} / \mathrm{HCV}$ coinfected patients followed at an urban HIV clinic by Mehta et al (21), 277 patients (33\%) were referred for HCV clinical care, of which 125 patients $(15 \%)$ were fully evaluated for eligibility and 29 patients $(3 \%)$ were started on treatment. In the present study, a bias may have been produced by the referral of selected patients who were more likely to adhere to and respond to therapy. For instance, patients with limited resources or greater disabilities may be less likely to be referred to the Toronto General Hospital Immunodeficiency Unit for treatment. This would imply that our results represent a best case scenario and, therefore, may not be generalizable to community practice. On the other hand, the characteristics of our cohort, such as age, sex, mean CD4 count, proportion with HCV genotype 1 and percentage of patients with relatively low HCV RNA levels, are comparable with recognized clinical trials $(9,13)$. With these issues in mind, our treatment response rates should be validated in future studies using a similar treatment protocol.

\section{CONCLUSION}

We report high levels of treatment adherence and response from a single centre treating HCV in HIV coinfected patients. All of the patients with $\mathrm{HCV}$ genotype 1 who demonstrated poor response to HCV therapy at eight weeks failed to achieve SVR. Every patient with either HCV genotype 2 or 3 achieved SVR with reduced treatment duration, dictated by their HCV viral kinetics at four and eight weeks on therapy. Future research in this field should attempt to confirm our findings with larger prospective study designs.

ACKNOWLEDGEMENTS: The authors thank the allied health care staff at the Toronto General Hospital Immunodeficiency Unit, including Pauline Murphy who helped with preliminary data collection, Joanne Daly and Christine Walach.

FUNDING: Gilead Sciences provided funding for the quantitative viral analyses. There were no other sources of funding support for this study.

The results of this study were presented at The Annual Canadian Association on HIV Research Conference in Montreal, Canada, on April 26, 2008.

DISCLOSURES: The authors of this study do not have a commercial interest or other associations that may pose a conflict of interest.

8. Chung RT, Andersen J, Volberding P, et al. Peginterferon alfa-2a plus ribavirin versus interferon alfa-2a plus ribavirin for chronic hepatitis C in HIV-coinfected persons. N Engl J Med 2004;351:451-9.

9. Carrat F, Bani-Sadr F, Pol S, et al. Pegylated interferon alfa-2b vs standard interferon alfa-2b, plus ribavirin, for chronic hepatitis $\mathrm{C}$ in HIV-infected patients: A randomized controlled trial. JAMA 2004;292:2839-48.

10. Torriani FJ, Rodriguez-Torres M, Rockstroh JK, et al. Peginterferon alfa-2a plus ribavirin for chronic hepatitis $\mathrm{C}$ virus infection in HIVinfected patients. N Engl J Med 2004;351:438-50.

11. Hadziyannis SJ, Sette H,Jr, Morgan TR, et al. Peginterferonalpha2a and ribavirin combination therapy in chronic hepatitis C: A randomized study of treatment duration and ribavirin dose. Ann Intern Med 2004;140:346-55.

12. Alvarez D, Dieterich DT, Brau N, Moorehead L, Ball L, Sulkowski MS. Zidovudine use but not weight-based ribavirin dosing impacts anaemia during HCV treatment in HIV-infected persons. J Viral Hepat 2006;13:683-9.

13. Ramos B, Nunez M, Rendon A, et al. Critical role of ribavirin for the achievement of early virological response to HCV therapy in HCV/HIV-coinfected patients. J Viral Hepat 2007;14:387-91. 
14. Thomas DL. The challenge of hepatitis $\mathrm{C}$ in the HIV-infected person. Annu Rev Med 2008;59:473-85.

15. Payan C, Pivert A, Morand P, et al. Rapid and early virological response to chronic hepatitis $\mathrm{C}$ treatment with IFN alpha2b or PEG-IFN alpha2b plus ribavirin in HIV/HCV co-infected patients. Gut 2007;56:1111-6.

16. Martin-Carbonero L, Nunez M, Marino A, et al. Undetectable hepatitis $\mathrm{C}$ virus RNA at week 4 as predictor of sustained virological response in HIV patients with chronic hepatitis C. AIDS 2008;22:15-21.

17. Clanon KA, Johannes Mueller J, Harank M. Integrating treatment for hepatitis $\mathrm{C}$ virus infection into an HIV clinic. Clin Infect Dis 2005;40(Suppl 5):S362-6.

18. Singal AK, Anand BS. Management of hepatitis $C$ virus infection in $\mathrm{HIV} / \mathrm{HCV}$ co-infected patients: Clinical review. World J Gastroenterol 2009;15:3713-24.
19. Cote P, Baril JG, Hebert MN, et al. Management and treatment of hepatitis $\mathrm{C}$ virus in patients with HIV and hepatitis $\mathrm{C}$ virus coinfection: A practical guide for health care professionals. Can J Infect Dis Med Microbiol 2007;18:293-303.

20. Sherman M, Shafran S, Burak K, et al. Management of chronic hepatitis C: Consensus guidelines. Can J Gastroenterol 2007;21(Suppl C):25C-34C.

21. Mehta SH, Lucas GM, Mirel LB, et al. Limited effectiveness of antiviral treatment for hepatitis $\mathrm{C}$ in an urban HIV clinic. AIDS 2006;20:2361-9.

22. McGovern B, Fiore J, Wurcel A, et al. Delivering therapy for hepatitis $\mathrm{C}$ virus infection to incarcerated HIV-seropositive patients. Clin Infect Dis 2005;41(Suppl 1):S56-62. 


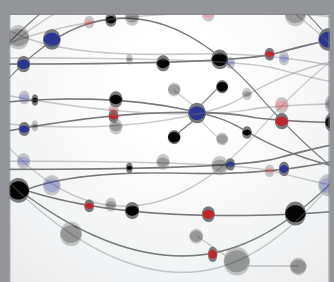

The Scientific World Journal
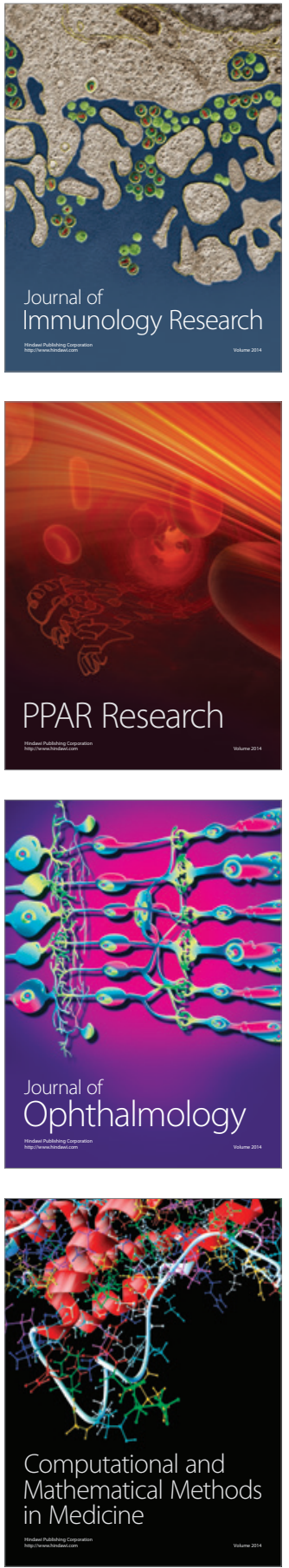

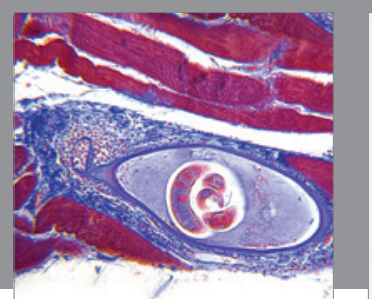

Gastroenterology Research and Practice

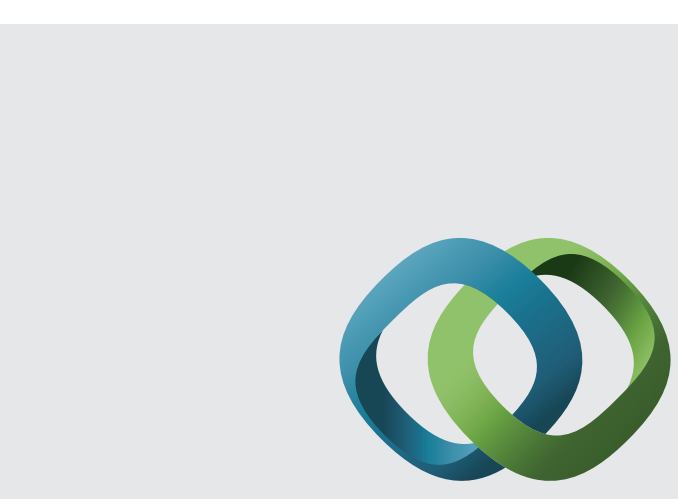

\section{Hindawi}

Submit your manuscripts at

http://www.hindawi.com
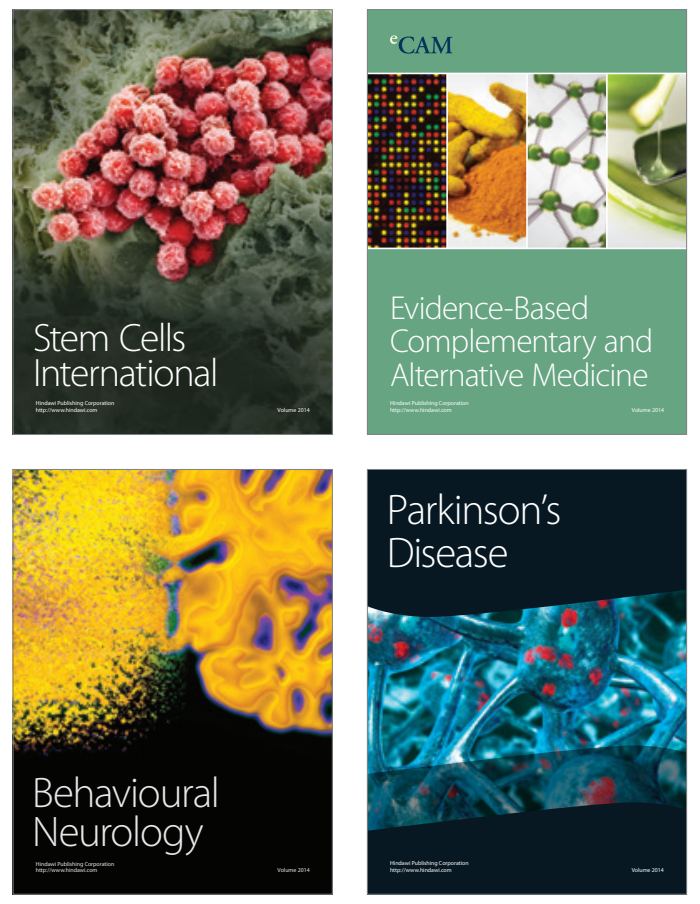
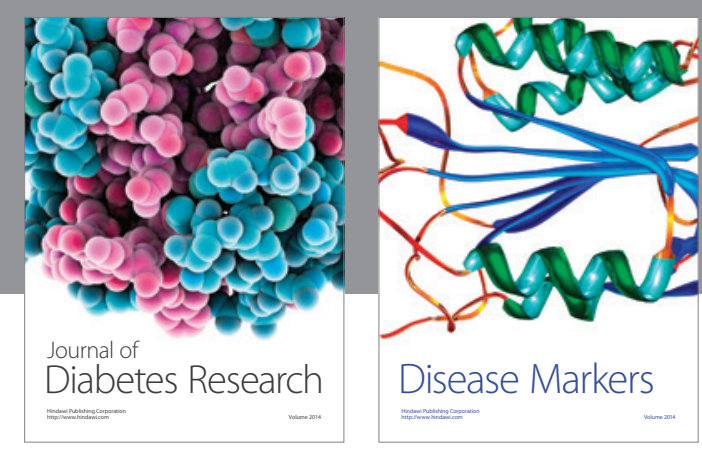

Disease Markers
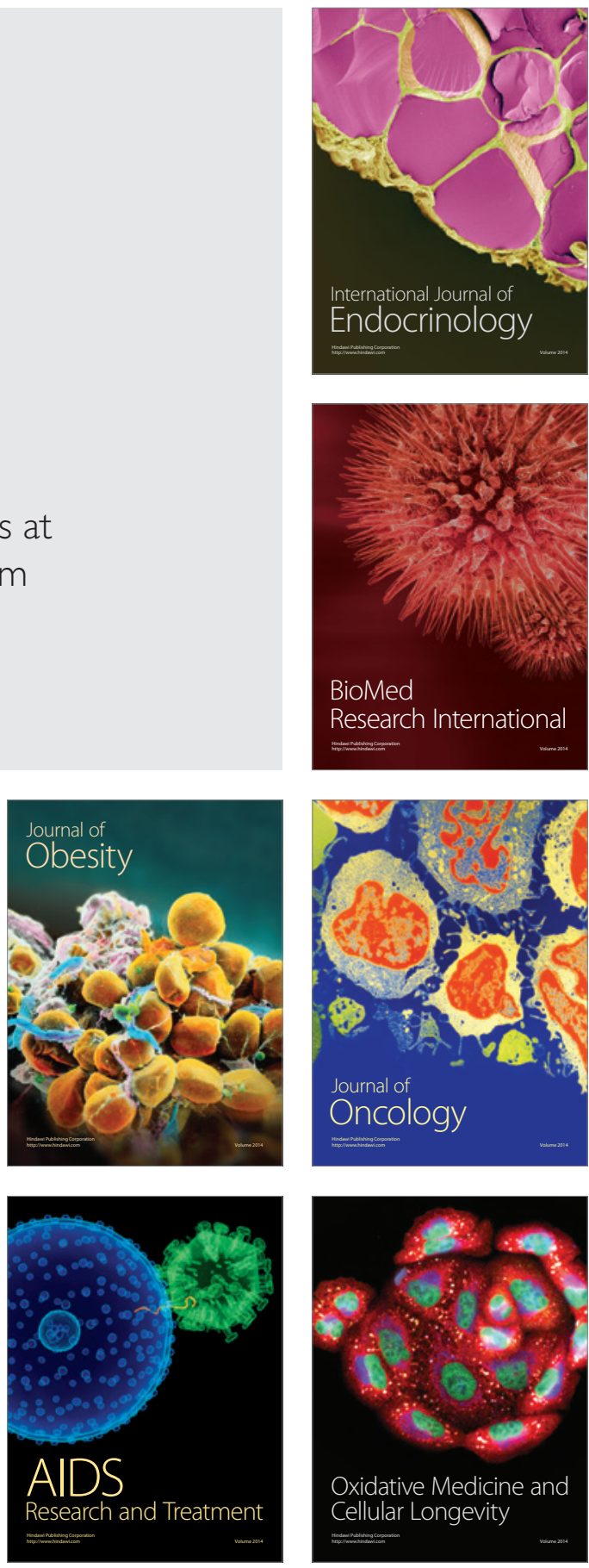